Anna Boguszewska

Pracownia Edukacji Plastycznej

Wydziat Artystyczny

UMCS Lublin

\title{
Kształcenie w zakresie projektowania książki w grafice użytkowej w szkolnictwie Warszawy w latach międzywojennych
}

Lata międzywojenne były czasem formowania się odrębności sztuki użytkowej, w tym grafiki, na gruncie polskiej sztuki. Były czasem ścierania się poglądów dotyczących granicy między rzemiosłem artystycznym a sztuką czystą. Uczelnie artystyczne stanowiły zarzewia środowisk opiniotwórczych, były miejscem permanentnych przemian programowych w zakresie kształcenia, doświadczeń i eksperymentów plastycznych oddziałujących na szersze środowisko artystyczne i społeczne. Na uczelniach artystycznych sztuki stosowane powoli znajdowały miejsce wśród sztuk czystych, stanowiąc o konieczności wprowadzania nowych dróg kształcenia. Projektowaniu ilustracji książkowej częstokroć odmawiano miana działalności artystycznej. W okresie międzywojennym pogląd, że przeceniając ilustracje, plakat czy znaczek pocztowy niszczy się sztukę czysta, byt nader powszechny ${ }^{1}$. Sztuki stosowane w drugiej połowie XX w. z trudem torowały sobie drogę do samodzielności, której zaczątek upatrywać należy w twórczości artystów okresu Młodej Polski².

Dzieje szkolnictwa artystycznego w Polsce, mimo licznych już na ten temat publikacji ${ }^{3}$, można traktować jako teren nadal odkrywany, wymagający dalszych szczegółowych

${ }^{1}$ W. Lam, Rozważania o sztuce, Poznań 1927; W. Lam, Jak posiąść wiedzę malarska, Lwów 1938; Liczne opinie wyrażane na łamach czasopism i prasy, przez artystów malarzy i krytyków sztuki, np. T. Czyżewskiego, W. Husarskiego, S. Zahorską wyrażały niezadowolenie z obecności sztuk użytkowych w programie kształcenia warszawskiej szkoły plastycznej.

2 J. Starzyński, Polska droga do samodzielności w sztuce, Warszawa 1973.

3 Wśród autorów najstarszych opracowań dziejów oraz materiałów źródłowych szkolnictwa artystycznego należy wymienić W. Łuszczkiewicza, W. Tatarkiewicza, W. Prokescha, W. Przanowskiego, J. Puciatą-Pawłowską, L. Ręgorowicza. Powojenne źródłowe prace K. Bartnickiej, M. Chamcówny, A. Chyczewskiej, dotyczą początków szkolnictwa artystycznego na byłych terenach Polski. Opracowania S. Kozakiewicza, A. Ryszkiewicza, oraz prace przyczynkarskie, monografie dotyczące życia artystycznego, kształcenia nauczycieli rysun- 
badań historyczno-oświatowych. Początki szkolnictwa artystycznego na terenie Polski związane są z miastem Krakowem ${ }^{4}$, Wilnem ${ }^{5}$ oraz Warszawą XVIII i XIX w.

Kształcenie artystów w Warszawie łączyć należy z panowaniem króla Stanisława Augusta. Jego inicjatywa - jako jedna pierwszych po wstąpieniu na tron - to utworzenie regularnej szkoły dla artystów, na wzór akademii we Francji czy we Włoszech. Przedsięwzięcie to dokumentuje korespondencja z 1767 r. Jej realizacja związana jest z osobą Marcelego Bacciarelliego działającego w Warszawie. Po śmierci króla w 1798 r., malarz, portrecista króla, który skupił wokół siebie uczniów, wykorzystując zaczątki utworzonego środowiska artystycznego, uzyskał koncesje na dalsze prowadzenie szkoły. W $1815 \mathrm{r}$. utworzony został Wydział Sztuk Pięknych przy Uniwersytecie Warszawskim, który mógł istnieć tylko do 1831 r. ${ }^{6}$ W 1844 r. powstaje Szkoła Sztuk Pięknych oraz Klasa Rysunkowa Wojciecha Gersona ${ }^{7}$, działające do 1918 r.

ku, nauczania rysunku w szkołach powszechnych i średnich A. Boguszewskiej, K. Dormus, J. Doroszewskiego, K. Lewickiego, J. M. Michałowskiego, I. J. Kamińskiego, J. Rossa, M. Porębskiego, A. Wojciechowskiego, A. M. Żukowskiej dotyczą i kształcenia artystycznego w XIX wieku oraz okresu międzywojennego. Monografie szkół artystycznych opracowali J. Dutkowski, J. i W. Ślesińscy, A. Załuski (ASP Kraków), K. Piwocki, W. Włodarczyk (ASP Warszawa), S. Teisseyr (Poznań). Wiele opracowań dotyczących historii sztuk plastycznych w Polsce dotyka rozwoju szkół artystycznych, nawet fragmentaryczne informacje w sposób istotny dopełniają całości obrazu (K. Iwanicka, B. Kowalska, M. Poprzęcka, M. Rzepińska, D. Wróblewska, W. Wierzchowska i in.).

${ }^{4}$ Akademia Sztuk Pięknych w Krakowie jest najstarszą uczelnią artystyczną w Polsce. W 1818 r. utworzono przy Uniwersytecie Jagiellońskim Oddział Sztuk Pięknych (Szkoła Rysunku i Malarstwa w ramach Oddziału Literatury Uniwersytetu Jagiellońskiego). Katedrę malarstwa prowadził Józef Brodowski, rysunku Józef Peszka, rzeźby - Józef Reidlinger. Zakres nauczania rozszerzał statut wydany przez rektora Uniwersytetu Jagiellońskiego Alojzego Estrajchera w 1932 r., odtąd nauczano sztuk graficznych: litografii i sztycharstwa. Po upadku powstania listopadowego w 1833 r. krakowską akademię przyłączono do Instytutu Technicznego. Jej nazwę zmieniono na Szkołę Rysunku i Malarstwa. Podtrzymano dotychczasowy program nauczania, w latach czterdziestych rozwinęła się w jej ramach tzw. Szkoła Litografii, współpracująca z zakładem Piotra Wyszkowskiego, gdzie odbywały się zajęcia z litografii oraz Instytutem Technicznym. W 1845 r. cech malarzy krakowskich znalazł swoje miejsce rozwoju przy Uniwersytecie Jagiellońskim. Dzieje szkoły kształtowała w dużej mierze kształtuje sytuacja polityczna miasta Krakowa. O wzroście znaczenia szkoły można mówić wraz z objęciem jej kierownictwa przez Władysława Łuszczkiewicza. Działania programowe i pedagogiczne w drugiej połowie XIX w. nadają szkole Władysław Łuszczkiewicz i Jan Matejko, kierując swoich uczniów w stronę malarstwa historycznego. Brak pracowni grafiki uniemożliwiał rozwój tej dziedziny sztuki na terenie szkoły. W 1873 r., kiedy dyrektorem Szkoły Malarstwa i Rysunku został Jan Matejko, nazwę szkoły zmieniono na Szkołę Sztuk Pięknych. Dzięki zabiegom Jana Matejki przyznano jej statut, stanowiący o randze szkoły wyższej. Przez posiadanie własnego statutu, po raz pierwszy w swojej historii stała się instytucją samodzielną. 175 lat nauczania malarstwa, rzeźby i grafiki w krakowskiej ASP, red. L. Ząbkowski, J. Nowakowski, S. Rodziński, I. Rybkowski, S. Wejman, A. Wiesiołowski, Wydział Malarstwa Akademii Sztuk Pięknych, Kraków, 1973, s. 134.

${ }^{5} \mathrm{Na}$ uniwersytecie wileńskim pod koniec XVIII w. nauczano sztuk plastycznych: malarstwa, rysunku, rzeźby i sztycharstwa. Zakres nauczania sztycharstwa - technik wypukłych i trawionych dostosowany był do potrzeb typografii i grafiki tekowej. Na początku wieku XIX zadomowiła się wśród technik graficznych litografia. Kształcenie w tym zakresie związane było z osobami Bogumila Kislinga, Józefa Saundersa, Fryderyka Lehmana, którym nieobce była typografia oraz ilustrowanie książek. Nauczanie sztuk plastycznych na Uniwersytecie Wileńskim zyskało status w organizacji wydziału w 1919 r. Patrz: K. Bartnicka, Polskie szkolnictwo artystyczne na przetomie XVIII i XIX w. 1764-1931, Wrocław, Warszawa, Kraków, Gdańsk, Łódź, 1971, s. $127-131$.

${ }^{6}$ W. Włodarczyk podaje 1815 r. jako datę utworzenia Wydziału Sztuk Pięknych przy Uniwersytecie Warszawskim, W. Tatarkiewicz - rok 1817.

7 Zob. M. Hendrykowska, Wojciecha Gersona idea wyższej użyteczności malarstwa, „Projekt” 1978, nr 5-6, s. 28-33;. M. Olszanicka, Wojciech Gerson, katalog wystawy monograficznej, Warszawa 1978, s. 29. 


\section{Miejska Szkoła Sztuk Zdobniczych i Malarstwa w Warszawie}

Już w niepodległej Polsce, w Warszawie od 1918 r., funkcjonuje Miejska Szkoła Sztuk Zdobniczych i Malarstwa (MSSZ) ${ }^{8}$. Na przełomie 1920/21 r. powstaje tam dział graficzny, w którym podjęto nauczanie w zakresie grafiki użytkowej. W listopadzie 1921 roku nauczanie grafiki użytkowej obejmuje Wacław Radwan. Sam ocenia swoją działalność następująco: w skutek nalegań W. Skoczylasa E. Trojanowskiego i T. Noskowskiego objątem nowo zaprojektowany dziat grafiki użytkowej. Zapoczatkowałem pierwsze kroki metodyczne samodzielnego dziatu grafiki użytkowej w Warszawie, a może i $i$ Polsce. [...] Zdaje się, że bytem pierwszym, który zapoczatkowat w szkołach artystycznych zagadnienie ksiażki jako całości, choć w ramach ogólnych ${ }^{9}$. Już w 1924 r. W. Radwan pozyskał dla Szkoły prasę litograficzną, co pozwoliło na rozwój techniki, litografii chętnie wykorzystywanej w projektowaniu książki. W 1927 r. szkoła prezentowana była na wystawie światowej w dziale grafiki, gdzie uzyskała Złoty Medal. W 1931 r. Szkoła posiadała maszynę drukarską oraz zestaw czcionek, czyli kompletny zestaw poligraficzny. Sytuacja ta umożliwiła rozwój nauczania w zakresie sztuki książki, poprzez pełną realizacje zadań projektowych. W latach 1931-1935 grafiki warsztatowej nauczał tam wybitny artysta i pedagog Aleksander Rak.

W 1937 r. w Paryżu na Międzynarodowej Wystawie Światowej W. Radwanowi powierzono kierownictwo Działu Szkolnictwa Artystycznego oraz przygotowanie reprezentacyjnej wystawy ${ }^{10}$. Działalność W. Radwana nagrodzono Dyplomem Honorowym.

\section{Warszawska Szkoła Sztuk Pięknych}

W 1904 r. powstaje - jako szkoła prywatna - Warszawska Szkoła Sztuk Pięknych, założona przez osoby pochodzące z kręgów artystycznych, finansowych i arystokratycznych. Sięgając do odezwy z 1902 r. wówczas organizującej się szkoły, autorstwa dyrektora szkoły Kazimierza Stabrowskiego, czytamy: Atali wobec wysoko stojących i uprawiajacych sztukę czysta akademii tak krakowskiej, jak i petersburskiej nie chcemy wytacznie tego typu szkoły otwierać, a pragniemy w szerszej mierze uwzględnić sztukę stosowana [...]. Nie chodzi nam o wykształcenie kopistów i rękodzielników, pojętnie przyswajających sobie obce wzory, ale o artystów prawdziwych, którzy by wzory te stworzyć potrafili. Sądzimy, że sztuka żywa być może w każdym dziele ręki ludzkiej i rękodziele arcydzieło żyć może ${ }^{11}$.

\footnotetext{
8 J. Puciata-Pawłowska, Dzieje Malarskiej Szkoły Sztuk Zdobniczych i Malarstwa, Warszawa 1939.

${ }^{9}$ Archiwum ASP, Warszawa, Życiorys Wacława Radwana z dnia 5 grudnia 1947 roku, Akta osobowe, K 511.

${ }^{10}$ Międzynarodowe Wystawy Światowe (Wystawy światowe) - cykliczne ekspozycje prezentujące dorobek kulturalny, naukowy i techniczny krajów i narodów świata. Ciałem zajmującym się organizacją wystaw jest Międzynarodowe Biuro Wystaw Światowych (Bureau International des Expositions), powstałe w 1928 r. w wyniku umowy międzynarodowej ratyfikowanej przez większość państw Ligi Narodów.

11 Za: K. Piwocki, Historia Akademii Sztuk Pięknych w Warszawie, Wrocław-Warszawa-Kraków, Wrocław, s. 23-24, por. K. Piwocki, Akademia Sztuk Pięknych w Warszawie, w: Polskie życie artystyczne w latach 1915-1939, red. A. Wojciechowski, Wyd. PAN, Warszawa 1974, s. 525 i in.
} 
W 1914 r. otrzymała na Wybrzeżu Kościuszkowskim własny gmach z fundacji Eugenii Kierbedziowej. Szkołę upaństwowiono w 1920 r. Poprzez wytrwałe zabiegi profesorów szkoły u władz oświatowych o status akademii, w dwa lata później przyznano jej nowy status $^{12}$. Otwarcie Szkoły Sztuk Pięknych (SSP) nastąpiło 11 marca 1923 r. ${ }^{13}$ Ustawa z dnia 23 marca 1932 r. ustala nazwę szkoły jako Akademia ${ }^{14}$, pełne prawa Szkoła uzyskuje dopiero w 1934 r. $^{15}$

Warszawska szkoła przyjmuje do realizacji koncepcję programową Józefa Czajkowskiego, która miała na celu zerwanie z podziałem sztuki na „sztukę czystą” i ,sztukę stosowaną"16 poprzez przełożenie tych dwóch rzeczywistości w całości nauczania. W rzeczywistości, poglądy na zadania szkoły były podzielone. Udział sztuk stosowanych w programach szkoły nie był tak oczywisty dla całego grona pedagogicznego. Nie zyskał aprobaty profesorów projekt poszerzenia kadry o osobę Jerzego Warchołowskiego, wybitnego propagatora sztuk stosowanych, który zapewne intensyfikowałby rozwój szkoły w kierunku sztuk użytkowych. Artysta-malarz Tytus Czyżewski protestował wobec łączenia grafiki użytkowej i sztuk czystych na płaszczyźnie programowej szkoły. Protestowali również inni artyści malarze z grona wykładowców szkoły. Ewolucja programów na rzecz sztuki stosowanej była powstrzymywana przez zwolenników koncepcji nauczania opartej na wyłącznej obecności „sztuki czystej”. Przy takich poglądach obstawali głównie artyści-malarze, profesorowie szkoły między innymi: Tytus Czyżewski, Felicjan Kowarski i Tadeusz Pruszkowski.

Katedrą Grafiki Warszawskiej Szkoły Sztuk Pięknych w latach 1922-1934 kierował Władysław Skoczylas. Jego działalność ważna jest nie tylko ze względu na jakość przemian organizacyjno-programowych w nauczaniu ale także działań na rzecz usamodzielnienia się dyscypliny grafiki. Skoczylas zapowiadał nową, „graficzna epokę” sztuki. Jej realizacja nastąpiła poprzez twórczość własną oraz wybitną działalność pedagogiczną. Wraz ze swoimi uczniami działał na rzecz upowszechnianie grafiki i krzewienia kultury plastycznej. Działania te żartobliwie nazywano „burzą ksylograficzną”, dostrzegamy w nich intencję wdrażania w życie społeczne elementów wychowania estetycznego. W. Skoczylas nie negował jednolitości sztuk, na plan pierwszy wysuwał jej rodzimy charakter. Fundamentem szkoły, a zwłaszcza szkoty artystycznej sa ideały jakie ta sztuka krzewi. [...] Naczelnym zadaniem naszym jest odnajdowanie i rozwój rodzimych pierwiastków twórczych, które by byly wyrazem naszej narodowej odrębności i charakteryzowaty jej kulturalny poziom. [...] Drugim naczelnym celem naszym musi być dążenie do osiagnięcia

12 Ustawa o Szkole Sztuk Pięknych w Warszawie z dnia 23 marca 1922 roku, Dz. Ustaw Rz. P. nr 24, poz. 197; Statut ukazał się w Rozporządzeniu Rady Ministrów z dnia 20 listopada 1922, Dz. Ustaw Rz. P. nr 32 , poz. 423.

13 Zob. Relacja F. Ruszcyca z otwarcia szkoły, F. Ruszczyc, Dzienniki, cz. 2: W Wilnie 1919-1932. Wybór, układ, opracowanie, wstęp i posłowie, E. Ruszczyc, Warszawa 1996, s. 229.

14 Strukturę organizacyjną szkoły oraz dokładną analizę warunków jej formowania podaje K. Piwocki, Historia Akademii Sztuk Pięknych w Warszawie, Wrocław-Warszawa-Kraków, s. 37-85.

15 Rozporządzenie Rady Ministrów z dnia 21 lutego 1934 r. dotyczyło również Akademii Sztuk Pięknych w Krakowie.

16 J. Czajkowski, Szkoła Sztuk Pięknych w Warszawie. Cele i zadania, Warszawa, 1928. 
w sztuce współczesnego wyrazu. Musimy tworzyć sztukę, która swa forma świadczyć będzie o epoce, w której powstała [...] Trzecim wreszcie hasłem naszym jest jedność sztuki. Marzymy o tym, aby wptyw nasz byt widoczny w naszym życiu [... $]^{17}$. Były to bardzo ważne stwierdzenia, torujące tożsamość polskiej sztuce nie tylko graficznej, doceniające jej wielostronny charakter wychowawczy i formalny.

Już po czterech latach pracy Skoczylasa w warszawskiej Szkole Sztuk Pięknych, zaprezentowana została pierwsza wystawa stowarzyszenia artystycznego „Ryt” ${ }^{18}$, skupiająca głównie jego uczniów. Świadczyła o nowym podejściu do grafiki oraz świadomym i konsekwentnym realizowaniu idei w nauczaniu. W nauczaniu na pierwszym miejscu stawiano zapoznanie studentów z technikami graficznymi i stylem pracy plynacym z materiatu i narzędzi ${ }^{19}$, na drugim - przygotowanie swoich uczniów do samodzielnej, indywidualnej pracy. Jako drogę realizacji tego założenia przyjmowano indywidualne wykonywanie kompozycji na dowolny temat. Skoczylas bezmyślne kopiowanie natury i kopiowanie wzorów odrzuca ${ }^{20}$. Konsekwentne podejście do wymienionych założeń zaowocowało indywidualnością twórców - absolwentów Wydziału Grafiki, stanowiącymi trzon chlubnej strony polskiej grafiki lat międzywojennych ${ }^{21}$.

J. Jakimowicz wskazując na dokonania W. Skoczylasa, podkreśla, że Przymierze Skoczylasa z użytkowością w pokoleniu uczniów wydało z jednej strony takie zjawisko jak precyzja książowego zdobnictwa u Chrostowskiego, z drugiej strony płaska dekoracyjność graficznych artystów, którzy byli zwani bliżej Bartłomiejczykiem [...], w sumie jednak warianty orientacje i różne temperamenty mieściły się bez reszty w prawie ogólnym programie Skoczylasowej szkoły, którą skonsolidowało ponadto założone przez mistrza w 1925 r. stowarzyszenie „Ryt”, jego wspólne subskrypcje graficzne, wybitny udział w zorganizowaniu w Warszawie Międzynarodowych Wystaw Drzeworytu²2. Mistrz drzeworytu skupił środowisko artystyczne, aby mogła się odrodzić polska szkoła graficzna reprezentowana przez drzeworyt oraz inne techniki graficzne.

W SSP w Warszawie w październiku 1926 r., jako wykładowca grafiki użytkowej, pracę dydaktyczną podjął Edmund Bartłomiejczyk. W 1930 r. zostaje powołany na katedrę grafiki użytkowej w stopniu profesora ${ }^{23}$. Była to pierwsza tego typu katedra w Polsce.

17 Za, K. Piwocki, Historia Akademii Sztuk..., s. 62; Zob. W. Skoczylas, O zadaniach Szkoty Sztuk Pięknych, „Gazeta Polska”, 1929, z dn. 18 grudnia; por. W. Skoczylas, O drogach wychowania estetycznego, „Szkoła Polska” 1917, nr 27.

18 Stowarzyszenie Polskich Artystów Grafików „Ryt” działające w latach 1925-1939 w Warszawie, powołane przez W. Skoczylasa i L. Gardowskiego. Członkami stowarzyszenia byli przeważnie uczniowie obydwu profesorów. Celem stowarzyszenia było doskonalenie sztuki drzeworytu. Organizowane prezentacje kształtowały ówczesne graficzne środowisko artystyczne.

19 Określenie W. Skoczylasa, Za: M. Wallis, Władysław Skoczylas, „Wiadomości Literackie” 1934, nr 16.

${ }^{20}$ Ibidem.

${ }^{21}$ M. Wallis, Władysław Skoczylas, „Wiadomości Literackie” 1934, nr 16, M. Wallis, Władysław Skoczylas, „Sztuki Piękne” IV, 1927/28, s. 201-220; M. Wallis, Najnowszy drzeworyt polski-szkoła Skoczylasa, w: M. Wallis, Sztuka polska dwudziestolecia, Warszawa 1959, s. 253-255; M. Wallis, Prace uczniów warszawskiej Akademii Sztuk Pięknych, „Wiadomości Literackie” 1934, nr 29 (556).

22 J. Jakimowicz, Warszawska grafika międzywojenna, „Projekt” 1980, nr 2, s. 6; Międzynarodowe Wystawy Drzeworytu miały miejsce w 1933 i 1936 r. w Warszawie.

${ }^{23}$ Archiwum ASP, Warszawa, Życiorys Edmunda Bartłomiejczyka z dn. roku, Akta osobowe, KD 91. 
Wysoki poziom artystyczny, jaki jej nadał Bartłomiejczyk, jego osobowość artystyczna stanowiła o kształtowaniu umiejętności graficznych studentów ASP w Warszawie do końca okresu międzywojennego. Praca pedagogiczna E. Bartłomiejczyka w warszawskiej SSP oparta była na studyjnym opracowaniu niewielkiej liczby zadań. Realizacja zadania trwała nawet pół roku, zwykle dotyczyła kilku wersji jednego zadania. Przy rozpoczynaniu zadania profesor żądał możliwe dużo projektów. Wybierał na początek jeden z projektów, uzasadniając wybór. Student realizował zadanie w wybranej technice graficznej. Opracowywane zadanie poddawane było wielokrotnym korektom, w których uaktywniał indywidualność studenta, nie narzucając rozwiązań. Profesor podkreślał, że z każdego z prezentowanych pomysłów można skorzystać, odpowiednio dopracowując wersję. Często były to następne etapy pracy w rozwiązaniu danego zadania. $\mathrm{W}$ ten sposób różnicowano formy plastyczne i rozwiązania w technikach graficznych.

W pierwszym roku specjalizacji grafiki użytkowej pierwszy do realizacji proponowany był temat typu: projekt papieru pakowego. Następnie przechodzono do ćwiczeń z zastosowaniem liternictwa, np. znak firmowy, plakat na wybrany temat w małym formacie. Drugi rok specjalizacji obowiązkowo dotyczył książki. Projektowano obwoluty, układy typograficzne stron, ozdobniki i ilustracje. Częstym tematem były realizacje plakatu w dużym formacie. Pracą dyplomową była najczęściej szata graficzna wybranej książki. Profesor dopuszczał inne tematy, o ile znajdowały uzasadnienie formalne i były osadzone w zainteresowaniach realizującego, np. Tadeusz Lipski graficznie przedstawił przebieg zawodów balonowych Gordona Bennetta ${ }^{24}$.

E. Bartłomiejczyka charakteryzowała serdeczna postawa w stosunku do studentów. Fachowość, ale i życzliwość, postawa wychowawcy, przewodnika w życiu, jest podkreślana we wspomnieniach jego uczniów, którzy nazywali popularnie profesora „Bartkiem”. „Przy korekcie dużo dyskutował z młodzieżą, nie narzucał jednak swego stylu, starając się wydobyć i rozwijać każdą indywidualność. Studentów traktował równomiernie, ale oceniając ich zdolności i możliwości, odpowiednio indywidualizował i dozował trudności zadań. Cechował go serdeczny i koleżeński stosunek do uczniów, pogodne usposobienie, a zarazem wyjątkowa sumienność i odpowiedzialność w pełnieniu zadań profesorskich. Zainteresowania i kontaktu ze studentami nie ograniczał jedynie do korekty. Zachęcał i podkreślał konieczność ogólnego rozwoju umysłowego, a stwarzany przez niego nastrój zaufania i koleżeńskiej zażyłości wyznaczały mu role powiernika w osobistych kłopotach i zmartwieniach młodych plastyków. Po ukończeniu studiów utrzymywał ścisły kontakt z byłymi uczniami, dbając o ich pracę, udzielając rad i dzieląc się swoim bogatym doświadczeniem" 25 .

Tadeusz Lipski pracował na stanowisku pomocnika techniczno-gospodarczego w pracowni prof. E. Bartłomiejczyka od 1 grudnia 1934 do 1 kwietnia 1935 r., kiedy to awansował na stanowisko asystenta ${ }^{26}$. Edward Manteuffel wybitny grafik, ilustrator jeszcze przed uzyskaniem dyplomu ASP, od 1 października 1936 r. do 31 sierpnia 1938 r., był

\footnotetext{
${ }^{24}$ K. Czarnocka , Edmund Bartłomiejczyk, „Przegląd Artystyczny” 1956, nr 3, s. 108.

25 Za: ibidem (tekst oparty na wspomnieniu ucznia E. Bartłomiejczyka T. Tuszyńskiego).

26 Stanowisko to piastował do 30 września $1936 \mathrm{r}$.
} 
młodszym asystentem prof. E. Bartłomiejczyka w Katedrze Grafiki Użytkowej. Boghan Bocianowski sprawował tę funkcję od 1 października $1938 \mathrm{r}$.

W ramach specjalizacji grafiki użytkowej została wprowadzona nauka projektowania książki. W roku 1924 przedmiotu książka i liternictwa uczył Ludwik Gardowski, zatrudniony w ramach godzin zleconych do 1929 r. Od 15 lutego 1927 r. Wydział Grafiki zasiliła stała, na pełnym etacie, obecność Bonawentury Lenarta, wybitnego specjalisty w zakresie liternictwa i grafiki książkowej, przybyłego z Uniwersytetu Wileńskiego, wcześniej pracującego w Krakowie. Objął on pracownię „sztuki książki” i introligatorstwa, praktycznie ją organizując. Jemu zawdzięcza SSP wyjątkowy poziom nauczania liternictwa, krzewienie zainteresowań wśród studentów introligatorstwem oraz grafiką książkową jako całościowym układem typograficznym. W pracowni książki i introligatorstwa w latach 1932-1934, jako instruktor liternictwa pracował Marian Jaschke; od 1 września 1936 r. Tadeusz Tuszyński był asystentem profesora B. Lenarta.

Grafika artystyczna w warszawskiej szkole prowadzona była przez wielu nauczycieli. Zajęcia warsztatowe drzeworytu obok Mistrza drzeworytu, W. Skoczylasa, prowadził Edward Czerwiński ${ }^{27}$. Był instruktorem grafiki od 17 listopada 1924 r., na stanowisko asystenta profesora Skoczylasa awansował 1 czerwca 1928 r., pracował do końca jego obecności w szkole. Pomoc techniczną w tej pracowni w roku akademickim 1931/1932 sprawował Arkadiusz Kondracki, w 1932/1933 r. Roman Kłopotowski, a 1933/1934 i 1934/1935 Fiszel Zylberberg.

W pracowni druku wklęsłego instruktaż technik metalowych w zimowym semestrze roku akademickim 1926/1927 sprawował Władysław Konopka. Następnie asystentem graficznych technik metalowych od 1 listopada 1927 do 30 czerwca 1930 r. był Henryk Grunwald. W roku akademickim 1928/1929 instruktorem technik graficznych był Józef Mazur. Na stanowisku instruktora grafiki 1 czerwca 1928 r. został zatrudniony Konrad Strzednicki, który pełnił tę funkcję do 31 sierpnia 1935 r., kiedy awansował na stanowisko asystenta. Jan Kędzierski pracował na stanowisku instruktora technik metalowych od 1 października 1928 r. do 30 czerwca 1929 r. W roku akademickim 1928/1929 i 1929/1930 graficzne techniki metalowe prowadził również instruktor Stefan Chmielarski. Henryk Grunwald 1 stycznia 1933 r. ponownie wrócił na stanowisko asystenta, pracując do 31 sierpnia 1935 r. Wacław Uzarski był instruktorem wklęsłych technik graficznych od 1 października 1930 r. do 30 czerwca 1934 r. Leon Pyszel został instruktorem technik metalowych 1 października 1934 r.; pracował do 30 września 1936 r. Stanowisko po nim przejął Wacław Chmielarski. Na stanowisku pomocnika gospodarczego w pracowni technik metalowych od 1 listopada 1930 r. pracował Franciszek Masiak, który awansował na stanowisko asystenta w 1 października 1938 r.

Po śmierci W. Skoczylasa Katedrą Grafiki kierował Leon Wyczółkowski, były to lata 1934-1936. Po jego śmierci, katedrę objął Stanisaw Ostoja-Chrostowski, najpierw od 1 września 1937 jako zastępca profesora grafiki, a od 1 lutego 1939 r. jako profesor nadzwyczajny. Jego asystentami byli: Wacław Waśkowski, od 1 września 1937 r. oraz Czesław Borowczyk do dnia 1 marca 1939 r. Liczne zmiany w obsadzie nauczycieli grafiki

27 Edward Czerwiński, związany ze szkołą do końca lutego 1938 r. 
świadczą o dynamice rozwoju oraz poszukiwaniach właściwego kierunku rozwoju kształcenia graficznego studentów. Sytuacje zmienności kadry, której zapewne towarzyszyły zmiany w programie nauczania, stabilizowało objęcie katedry przez S. Ostoję-Chrostowskiego. Ponownie nadał on rozwojowi katedry grafiki dynamiki i rozmachu. Służył swoim talentem oraz doświadczeniem, które zdobywał pod kierunkiem Skoczylasa, Bartłomiejczyka podczas studiów w Szkole Sztuk Pięknych ${ }^{28}$ oraz w czasie kierowania Doświadczalną Pracownią Graficzną w Salezjańskiej Szkole Rzemiosł w Warszawie.

Około 1930 r. ustaliła się liczba katedr i program kształcenia, dalsze lata nie przyniosły istotnych zmian organizacyjno-programowych ${ }^{29}$. Dwa pierwsze lata programu nauczania z roku akademickiego 1937/38 dla kierunków: malarstwo, grafika, architektura wnętrz, studium dla kandydatów na nauczycieli rysunku, był jednakowy. Na pierwszym roku przewidziana została nauka liternictwa w wymiarze 2 godzin tygodniowo (przez 2 semestry), realizowana przez B. Lenarta.

Po dwóch latach nauki studenci byli na etapie tzw. półdyplomu i wybierali specjalizację. Z zakresu grafiki wybrać mogli grafikę artystyczną lub grafikę użytkową. Na specjalizacji grafikę artystyczną, przedmiot główny - grafika artystyczna prowadził profesor S. Ostoja-Chrostowski w wymiarze 20 godzin ćwiczeń przez 4 semestry. Grafikę użytkową prowadził E. Bartłomiejczyk w przez 2 semestry w wymiarze 10 godzin ćwiczeń. Przedmiot książka i liternictwo obowiązywał przez 2 semestry w wymiarze 2 godzin tygodniowo.

Na specjalizacji grafika użytkowa, za przedmiot główny - grafikę użytkową - odpowiadał E. Bartłomiejczyk, prowadził zajęcia przez 4 semestry w wymiarze 20 godzin ćwiczeń. Wspomagający przedmiot, książka i liternictwo, obowiązywał tak jak na specjalności grafiki artystycznej przez 2 semestry w wymiarze 2 godzin tygodniowo. Grafikę artystyczną prowadził profesor S. Ostoja-Chrostowski w wymiarze 10 godzin ćwiczeń przez 2 semestry.

Studenci Katedry Malarstwa przechodzili kurs graficzny na III roku studiów, grafika artystyczna i użytkowa realizowana była przez 2 semestry w wymiarze 10 godzin ćwiczeń. Dyplom artystyczny można było przedstawić w ciągu 10 lat od uzyskania absolutorium.

W taki sposób formowało się Studium Grafiki warszawskiej szkoły przy wybitnym udziale E. Bartłomiejczyka, S. Ostoi-Chrostowskiego, W. Skoczylasa. Przygotowało w doskonałym warsztacie, dającym podstawy do uprawiania grafiki książki, nowe pokolenie artystów. Osobiste zainteresowania S. Ostoi-Chrostowskiego oraz E. Bartłomiejczyka sztuką książki pozytywnie oddziaływało na indywidualne poszukiwania twórcze studentów. Studia graficzne zapewniały uzdolnionej młodzieży solidne podstawy w zakresie artystycznych technik graficznych, głównie drzeworytu, miedziorytu i litografii oraz grafiki użytkowej.

W warszawskiej szkole w programie nauczania obecny był nurt sztuki stosowanej również w zakresie malarstwa dekoracyjnego, wprowadzonego przez Józefa Czajkow-

28 Dyplom z grafiki uzyskał 14 kwietnia 1934 r.

29 K. Piwocki, Historia Akademii Sztuk..., s. 68. 
skiego, kontynuowane przez Wojciecha Jastrzębowskiego, Leonarda Pękalskiego, Karola Tichy’ego. Obecność sztuki stosowanej było nowością w tego typu szkole, której byli świadomi autorzy programów i konsekwentnie jej bronili. Obecność wybitych artystów grafików, rzeźbiarzy oraz malarzy w gronie pedagogicznym szkoły znakomicie oddziaływało na rozwój artystyczny kształcącej się młodzieży. Uprawianie grafiki użytkowej przez profesorów akademickich, oddziaływało na szerszy krąg środowiska plastycznego, przekładało się na wysoką jakość tworzonych przez nich projektów ilustracji książkowych, plakatów i innych form graficznych i malarskich. Studenci czerpali te umiejętności od nauczycieli, czemu dali wyraz w swoich pracach nagrodzonych na wystawie paryskiej ${ }^{30}$. Za zasadnością zmiany nurtu kształcenia opowiadali się E. Bartłomiejczyk, J. Czajkowski, W. Jastrzębowski, S. Ostoja-Chrostowski, L. Pękalski, E. Trojanowski, W. Skoczylas, $\mathrm{K}$. Tychy oraz niektórzy krytycy sztuki ${ }^{31}$. Po latach Jan Białostocki ocenia ten czas następująco: we wczesnej i średniej fazie swego istnienia Szkoła przejawiała tendencje, bliskie występującym wówczas w najbardziej postępowych środowiskach pedagogiki artystycznej początków XX wieku - w Weimerze, Dessau, Berlinie. Byty to dążenia do głębokiego powiąania sztuki z życiem społecznym, do ukierunkowania wykształcenia artystycznego na użyteczność, do funkcjonalizmu z jednej strony, a do odnowy tradycji rzemiosła artystycznego a drugiej. [...] warszawska Akademia [...] w swym programie działalności międzywojennej może stanać obok najbardziej nowatorskich naówczas szkól, takich jak Bauchaus [...] w swej strukturze wyprzedziła niejako tendencje, które skłonity w wielu miastach Niemiec do łaczenia akademii sztuk ze szkołami rzemiosła i przemystu artystycznego ${ }^{32}$.

\section{Doświadczalna Pracownia Graficzna w Salezjańskiej Szkole Rzemiosł w Warszawie}

Analizując kształcenie artystów grafików w zakresie sztuki książki warto wspomnieć, że Warszawie w 1919 r., z inicjatywy proboszcza parafii św. Antoniego, ks. prałata Jana Siemca, Towarzystwo Salezjańskie przyjęło działalność w parafii. Powstał Zakład Salezjański im. Księdza Siemca w Warszawie. Salezjanie uzyskali od ministerstwa koncesję na Salezjańską Szkołę Rzemiosł z działami: krawiecki, szewski, stolarski i ślusarski. Cztery lata później placówka wzbogaciła się o dział introligatorsko-drukarski. Z racji potrzeb znalazł on się w centrum zainteresowania władz szkoły, był intensywnie rozbudowany jako dział graficzny. W trakcie kształcenia uczniów tego kierunku, korzystano z istniejącej drukarni salezjańskiej.

${ }^{30}$ M. Rogoyska, Paryskie zwycięstwo sztuki polskiej w 1925 r., w: Z zagadnień plastyki polskiej w latach 1918-1939, red. J. Starzyński, Wrocław-Warszawa-Kraków 1963, s. 21.

${ }^{31}$ Mieczysław Wallis publikował w zakresie krytyki artystycznej, latach między wojnami w „Sztukach Pięknych”, „Wiadomościach Literackich” oraz prasie warszawskiej

32 J. Białostocki, 75 lat ASP, 1904-1980, ASP, (wstęp), Warszawa 1980, s. 9, 12. 
Od 1931 r. w tej szkole rysunku, kompozycji oraz historii grafiki i sztuki drukarskiej zaczął nauczać S. Ostoja-Chrostowski. Z jego inicjatywy w Salezjańskiej Szkole Rzemiosł został przeorganizowany dział graficzny, powstała Doświadczalna Pracownia Graficzna w Warszawie. Jej działalność nastawiona była na eksperyment i nowatorstwo, takim programem zyskała sobie zainteresowanie środowisk twórców książ$\mathrm{ki}^{33}$. Wśród nich obecny był najwybitniejszy polski typograf i liternik Adam Półtawski. Realizowano tam wiele interesujących założeń typograficznych, między innymi druki bibliofilskie polskich towarzystw bibliofilów. ${ }^{34} \mathrm{~W}$ roku 1933 szkoła ta otrzymała prawa szkół państwowych i rangę gimnazjum graficznego. Czasy wojny poważnie ograniczyły działalność placówki ${ }^{35}$.

\section{Szkoła Przemysłu Drukarskiego w Warszawie}

Kolejną warszawską placówką szkolną, interesująca ze względu na kształtowanie kultury pięknej książki, była Szkoła Przemysłu Drukarskiego. Zorganizowana została w roku szkolnym 1926/1927 jako pierwsza placówka tego typu w Polsce. Istniała na mocy koncesji udzielonej Towarzystwu Kształcenia Zawodowego Grafików przez Ministerstwo WRiOP z dnia 9 czerwca $1926 \mathrm{r}^{36}$ Zamierzeniem w powołaniu tej szkoły było przygotowanie pracowników, którzy stana się w przyszłości podwalina przemysłu graficznego ${ }^{37}$. Ten wielki wysiłek organizacyjny podjęty został z myślą o podniesieniu jakości produkcji książki polskiej przez podnoszenie kwalifikacji pracowników szeroko pojmowanej poligrafiki. Uroczyste otwarcie szkoły nastąpiło 20 września 1926 rok przy ulicy Składowej 3 w gmachu Muzeum Przemysł i Rolnictwa.

Szkoła kształciła uczniów w zakresie drukarstwa, litografii i fotochemigrafii, a więc w niepełnym zakresie potrzeb ówczesnego przemysłu poligraficznego. Cykl kształcenia obejmował trzy lata. Przed uzyskaniem świadectwa ukończenia szkoły obowiązywała roczna praktyka w przemysłowych zakładach graficznych. Niewystarczające warunki, jakie zapewniły wykorzystywane sale wykładowe budynku szkolnego i oficyny Muzeum Przemysłu i Rolnictwa, skłoniły organizatorów szkoły do radykalnej decyzji - budowy dostosowanego do potrzeb szkoły gmachu. Starania powiodły się, w 1928 r. podjęto budo$w^{38}$. Można było planować rozwój szkoły, istniejące już działy wymagały specjalistycz-

33 Archiwum ASP, Warszawa, Stanisław Ostoja- Chrostowski., Akta osobowe, KD 6.

${ }^{34}$ A. Pietrzak, S. Ostoja- Chrostowski (1900-1947), grafika, ekslibrys, rysunki i matryce graficzne ze zbiorów Biblioteki Narodowej, Biblioteka Narodowa, Warszawa, s. 10.

${ }^{35}$ Funkcjonował jedynie dział wydawniczy do działa do wybuchu powstania warszawskiego, we wrześniu 1944 r. w dużej części uległy zniszczeniu budynki szkoły i drukarni.

${ }^{36} \mathrm{Nr}$ IIIDR. 8659/26 za: Sprawozdanie z działalności Szkoły Przemystu Graficznego w warszawie za rok 1927/8, w: Rocznik 1927/1928, Szkoła Graficzna w Warszawie, Warszawa 1928, s. 2.

37 Rocznik 1927/1928, Szkoła Graficzna w Warszawie, Warszawa 1928, s. 1.

38 Budowa realizowana z zasiłków Ministerstwa WRiOP; Projekt: architekt Czesław Przybylski; gmach usytuowany przy zbiegu ulic Zakroczymskiej i Konwiktorskiej; 15 października 1928 r. uroczyste poświęcenie fundamentów szkoły. 
nych pracowni i warsztatów, nieobecne w cyklu kształcenia było introligatorstwo. Składacze i maszyniści drukarscy kształcili się na kierunku drukarstwo. Dział litografii kształcił rysowników, przedrukarzy i maszynistów litograficznych, natomiast w dziale fotochemigraficznym kształceni byli fotografowie i trawiacze technik drukarskich.

Do szkoły przyjmowano młodzież z przygotowaniem 7-letniej szkoły powszechnej lub 3-letniego gimnazjum. Kandydaci zdawali egzamin z j. polskiego, arytmetyki i rysunku odręcznego. Przechodzili badania lekarskie i psychotechniczne. W roku szkolnym 1927/28 w dwóch klasach pierwszych i jednej drugiej kształciło się: 22 składaczy, 11 maszynistów drukarskich, 24 litografów i 28 specjalistów fotochemigrafii. Nauka odbywała się w godzinach 8-18, z dwugodzinną przerwą obiadową.

Szkołą kierował Stanisław Dąbrowski, nauczyciel historii sztuki. Kierownikiem pracowni drukarskiej był nauczyciel rysunku zawodowego Bolesław Pisarkiewicz. Pracownią litograficzną i fotochemigraficzną kierował nauczyciel teorii zawodu, Wilhelm Stonowski. Naukę rysunku odręcznego prowadził Julian Bohdanowicz. Praktyczną naukę zawodu prowadzili instruktorzy: w dziale składaczy - Kajetan Fioder, w dziale fotochemigraficznym - Julian Jędrzejewski ${ }^{39}$, Mieczysław Kwiatkowski, w dziale litografii - Bolesław Kuleszyński, a następnie Marian Warwaszyński wraz z Witoldem Wójcikowskim. Roman Osiński prowadził praktykę w dziale maszyn drukarskich, a Zenon Tomaszewicz w dziale maszyn offsetowych. Absolwentem szkoły był wybitny artysta grafik, plakacista i ilustrator Henryk Tomaszewski ${ }^{40}$. W szkole realizowano zamówienia , na wszelkie roboty w zakresie sztuki graficznej: drukarskie, litograficzne i fotochemigraficzne ${ }^{41}$ ". Tabela 1 prezentuje strukturę programu oraz nazwiska nauczycieli odpowiadających za przedmioty nauczania.

\footnotetext{
39 Julian [Juljan] Jędrzejewski zmarł 15 sierpnia 1928 r.

${ }^{40}$ Archiwum ASP w Warszawie, Zbiór Akt ASP, sygn. 1548.

${ }^{41}$ Ogłoszenie na okładce w: Rocznik 1928/1929, Szkoła Graficzna w Warszawie, nr 2, Warszawa 1929.
} 
Tabela 1. Struktura programu Szkoły Przemysłu Drukarskiego z roku szkolnego 1928/1929 w Warszawie ${ }^{42}$.

\begin{tabular}{|c|c|c|c|c|c|c|}
\hline \multirow{2}{*}{ Lp. } & \multirow{2}{*}{ Przedmiot nauczania } & \multicolumn{4}{|c|}{ Wymiar godzin } & \multirow{2}{*}{ Nauczyciel przedmiotu } \\
\hline & & kl. I & kl. II & kl. III & razem & \\
\hline 1. & Religia & 1 & 1 & - & 2 & Ks. Kazimierz Wójcik \\
\hline 2 & $\begin{array}{l}\text { J. polski i stylistyka handlowo-prze- } \\
\text { mysłowa }\end{array}$ & 4 & 3 & 1 & 8 & Józef Targowski \\
\hline 3. & $\begin{array}{l}\text { Arytmetyka i rachunki } \\
\text { przemysłowe }\end{array}$ & 2 & 1 & 1 & 4 & Wiesław Różański \\
\hline \multirow[t]{3}{*}{4.} & Nauka o Polsce: & & & & \multirow{3}{*}{3} & \multirow{3}{*}{ Michał Geisler } \\
\hline & krajoznawstwo & 2 & & & & \\
\hline & nauka o obywatelstwie & & & 1 & & \\
\hline 5. & $\begin{array}{l}\text { Fizyka ogólna i techniczna oraz } \\
\text { maszynoznawstwo dla maszynistów }\end{array}$ & 2 & 1 & 1 & 4 & B. Lebiedziński \\
\hline 6. & Chemia [chemja] & 2 & - & - & 2 & $\begin{array}{l}\text { Michał Kossakocki } \\
\text { Stanisław Szymankiewicz }\end{array}$ \\
\hline 7. & $\begin{array}{l}\text { Materiałoznawstwo } \\
\text { [materjałoznawstwo] }\end{array}$ & - & 2 & - & 2 & \\
\hline 8. & Higiena & - & - & 1 & 1 & Leopold Jokiel \\
\hline \multirow[t]{3}{*}{9.} & Rysunki odręczne i zawodowe: & & & & \multirow{3}{*}{12} & \multirow{3}{*}{$\begin{array}{l}\text { J. Bohdanowicz } \\
\text { Bolesław Pisarkiewicz }\end{array}$} \\
\hline & Rysunki odręczne & 4 & 2 & - & & \\
\hline & Rysunki zawodowe & - & 2 & 4 & & \\
\hline 10. & Historia sztuki & - & 2 & - & 2 & S. Dąbrowski \\
\hline 11. & Historia sztuki graficznej & & & 1 & 1 & S. Dąbrowski \\
\hline 12. & Kreślenie geometryczne & & & & & B. Lebiedziński \\
\hline 13. & Ćwiczenia cielesne & 2 & 1 & 1 & 4 & Aleksander Moskwa \\
\hline 14. & Teoria zawodu & 1 & 1 & - & 2 & Wilhelm Stonowski \\
\hline 15. & $\begin{array}{l}\text { Ćwiczenia praktyczne w pracow- } \\
\text { niach }\end{array}$ & 22 & 30 & 36 & 88 & $\begin{array}{l}\text { Kajetan Fioder, Julian Jędrzejewski, } \\
\text { Bolesław Kuleszyński, Roman } \\
\text { Osiński, Zenon Tomaszewicz, Marian } \\
\text { Warwaszyński, Witold Wójcikowski }\end{array}$ \\
\hline & Razem & 46 & 46 & 46 & 138 & \\
\hline
\end{tabular}

W roku szkolnym 1928/1929 szkoła osiągnęła pełną strukturę organizacyjną. Program zachował zasadniczy trzon przedstawionej konstrukcji programowej do końca funkcjonowania szkoły, jednak w miarę uzyskiwanego doświadczenia wprowadzono niezbędne korekty i znaczne poszerzenia programu. Ewaluowały niektóre nazwy i zakres programowy przedmiotów nauczania. Tabela 2 prezentuje wykaz przedmiotów z roku szkolnego 1933/1934 specjalności najbliższej kształtowaniu sztuki książki - rysownika litograficznego.

42 Opracowano na podstawie: Rocznik 1927/1928, Szkoła Graficzna w Warszawie, Warszawa 1928, Rocznik 1928/1929, Szkoła Graficzna w Warszawie, nr 2, Warszawa 1929 
Tabela 2. Wykaz przedmiotów z roku szkolnego 1933/34 w specjalności rysownika litograficznego z uwzględnieniem zmian ${ }^{43}$

\begin{tabular}{|c|c|c|}
\hline Lp. & $\begin{array}{l}\text { Przedmioty nauczania z wersji } \\
\text { programowej z roku szkolnego } \\
\qquad 1933 / 1934\end{array}$ & $\begin{array}{l}\text { Uwagi - uwzględnienie zmian z pierwszej wersji programowej } \\
\text { szkoły }\end{array}$ \\
\hline 1. & Praktyczna nauka zawodu & Ćwiczenia praktyczne w pracowniach \\
\hline 2. & maszynoznawstwo & Nowy przedmiot \\
\hline 3. & $\begin{array}{l}\text { Rysunki geometryczne odręczne } \\
\text { i zawodowe wraz z liternictwem }\end{array}$ & $\begin{array}{l}\text { Włączono zakres przedmiotu kreślenie geometryczne oraz } \\
\text { poszerzono programu o zakres liternictwa }\end{array}$ \\
\hline 4. & Higiena ogólna i zawodowa & Wcześniej: Higiena \\
\hline 5. & Metodyka technik graficznych & Przedmiot nowy \\
\hline 6. & Nauka o barwach & Przedmiot nowy \\
\hline 7. & Czytanie rękopisów i korekta & Przedmiot nowy \\
\hline 8. & Odlewnictwo i galwanoplastyka & Przedmiot nowy \\
\hline 9. & Fotochemia i optyka fotograficzna & Przedmiot nowy \\
\hline 10. & $\begin{array}{l}\text { Historia sztuki ogólnej i sztuk } \\
\text { graficznych }\end{array}$ & $\begin{array}{l}\text { połączono przedmiot o nazwie historia sztuki graficznej } \\
\text { i historia sztuki }\end{array}$ \\
\hline 11. & $\begin{array}{l}\text { Chemia ogólna techniczna } \\
\text { i technologia materiałów }\end{array}$ & $\begin{array}{l}\text { Wcześniej: Chemia } \\
\text { Włączono treści przedmiotu materiałoznawstwo }\end{array}$ \\
\hline 12. & $\begin{array}{l}\text { Chemia analityczna z ćwiczeniami } \\
\text { laboratoryjnymi [laboratoryjnemi] }\end{array}$ & $\begin{array}{l}\text { Wcześniej: Chemia } \\
\text { Znaczne uszczegółowienie treści }\end{array}$ \\
\hline 13 & $\begin{array}{l}\text { Polski [j. polski] (dzieje kultury } \\
\text { polskiej ) }\end{array}$ & Wcześniej: Polski i stylistyka handlowo-przemysłowa \\
\hline 14 & Nauka o Polsce współczesnej & $\begin{array}{l}\text { Wcześniej: Nauka o Polsce: krajoznawstwo, nauka o obywatel- } \\
\text { stwie }\end{array}$ \\
\hline 15 & $\begin{array}{l}\text { Rachunki przemysłowe, księgo- } \\
\text { wość i korespondencja handlowa }\end{array}$ & $\begin{array}{l}\text { Wcześniej: Arytmetyka i rachunki przemysłowe } \\
\text { Poszerzenie o księgowość i korespondencję handlową }\end{array}$ \\
\hline 16. & Ustawodawstwo przemysłowe & Przedmiot nowy \\
\hline 17. & Nauka o technikach graficznych & Przedmiot nowy \\
\hline 18. & Maszynoznawstwo & $\begin{array}{l}\text { Przedmiot nowy, wyłączony z przedmiotu Fizyka ogólna } \\
\text { i techniczna oraz maszynoznawstwo dla maszynistów }\end{array}$ \\
\hline 19. & Fizyka ogólna i techniczna & $\begin{array}{l}\text { Wcześniej: Fizyka ogólna i techniczna oraz maszynoznawstwo } \\
\text { dla maszynistów wyłączono z treści maszynoznawstwo } \\
\text { w osobny przedmiot }\end{array}$ \\
\hline 20. & Ćwiczenia cielesne & Bez zmian \\
\hline 21. & Religia & Bez zmian \\
\hline 22. & & $\begin{array}{l}\text { Zlikwidowano przedmiot Teoria zawodu, maszynoznawstwo } \\
\text { treści włączając do innych przedmiotów }\end{array}$ \\
\hline
\end{tabular}

43 Opracowano na podstawie: Rocznik 1927/1928, Szkoła Graficzna w Warszawie, Warszawa 1928; Rocznik 1928/1929, Szkoła Graficzna w Warszawie, nr 2, Warszawa 1929; Świadectwo ukończenia Szkoły Graficznej w Warszawie z roku szkolnego 1933/34, Archiwum ASP w Warszawie, Zbiór Akt ASP, sygn. 1548. 
Kontynuowano budowę nowego gmachu, zaplanowanego z rozmachem (kubatura 19 000m kw.) W jednej części budynku przewidziano 9 sal lekcyjnych dla 50 uczniów każda, aulę, czytelnię, audytorium fizyczno-chemiczne wraz z pomieszczeniem pomocniczym. Część druga mieściła sale ćwiczeń praktycznych dla wszystkich działów, dwupiętrową halę maszyn litograficznych, drukarskich i fotochemigraficznych. Spełniała ona wymagania budynku przemysłowego. Gmach posiadał część trzecią z mieszkaniami dla pracowników szkoły. Pod koniec roku szkolnego 1930/1931 szkołę przeniesiono do nowego budynku przy ul. Konwiktorskiej 2. Dnia 20 sierpnia 1931 r. szkoła uroczyście przyjęła imię, patronem szkoły został Marszałek Józef Piłsudski. Do końca lat 30. funkcje dyrektora szkoły piastował S. Dąbrowski, utrzymując stałość kadry i programu. Z nastaniem okupacji hitlerowskiej Szkoła Przemysłu Graficznego została zamknięta.

\section{Szkoła Sztuk Pięknych im. W. Gersona}

W latach 30. XX w. w Warszawie działała prywata 4-letnia Szkoła Sztuk Pięknych im. W. Gersona, zajmująca - ze względu na wysoki poziom nauczania - czołowe miejsce wśród szkół prywatnych. Funkcję dyrektora szkoły sprawował Feliks Słupski, a następnie Michał Bylina. Pierwsze grono nauczycielskie stanowili: Stanisław Bagiński, Adam Grabowski, Lucjan Jagodziński, Tadeusz Nartowski ${ }^{44}$. Pod koniec lat 30. Michał Bylina prowadził wraz Leonem Ormezowskim pracownię malarską (kurs II, III, IV). Malarstwo sztalugowe i ścienne uzupełniał Czesław Wdowiszewski (kurs II, III, IV).

Szczególnie wyróżniający poziom prezentowali słuchacze w zakresie rysunku i grafiki warsztatowej, w pracowni Aleksandra Raka (Rakka) ${ }^{45}$, który podjął pracę w szkole, ucząc tych przedmiotów od 1936 r. ${ }^{46}$ Jego wyjątkowe umiłowanie sztuki, konsekwencja w pracy ze studentem przynosiła znaczące sukcesy pedagogiczne. Wprowadzono również nauczanie z zakresu grafiki użytkowej, którą prowadził Maciej Nehring ${ }^{47}$.

Kształcenie artystów grafików warunkuje poziom grafiki stosowanej, w tym sztuki książki. Poziom formalny ilustracji książkowej jest bezpośrednio zależny od talentu twórcy. Droga rozwoju jego uzdolnień związana jest z przebiegiem jego kształcenia, organizacji programowych szkół artystycznych oraz osobowości nauczycieli artystów, którzy tworzą warunki wrastania możliwości twórczych młodego artysty. Kształcenie specjalistyczne w szkolnictwie artystycznym przyszłych artystów plastyków ma tu istotne znaczenie. Koncepcje kształcenia w warszawskim szkolnictwie plastycznych i typograficznym

\footnotetext{
${ }^{44}$ Kronika Artystyczna, „Sztuki Piękne” 1933, s. 37.

${ }^{45}$ Aleksandra Rakk - pisownia nazwiska przedwojenna, artysta w czasie II wojny uprościł pisownię nazwiska. Rozmowa z córką artysty Martą Rak-Podgórską, z dnia 24 kwietnia 2010 r.

46 Sztuka poza czasem. Aleksandra Rak (1899-1978), Katowice 1999, s. 26.

47 Ze szkoly im. Gersona, „Plastyka” 1938, nr 6, s. 177-178.
} 
w okresie międzywojennym, wiążą się z nadawaniem jej wysokiej rangi, postrzeganiem istotnej roli sztuk stosowanych w życiu społecznym, również w aspekcie kultury wizualnej. Kształcenie twórców związanych ze stroną graficzną książki w omawianym środowisku stanowi bardzo chlubną kartę polskiego szkolnictwa.

\title{
Education in Design of Books in Applied Graphics in the Educational System of Warsaw in the Inter-War Period (1918-1939)
}

\begin{abstract}
Summary
The article is devoted to the history of artistic educational system in Warsaw in the inter-war period. The author analyses the methods of teaching the students of applied arts how to insert graphic elements in books. The following institutions are taken into account: Miejska Szkoła Sztuk Zdobniczych i Malarstwa, Warszawska Szkoła Sztuk Pięknych, Doświadczalna Pracownia Graficzna operating in Salezjańska Szkoła Rzemiosł, Szkoła Przemysłu Drukarskiego and the W. Gerson Szkoła Sztuk Pięknych. The abovementioned public and private artistic schools followed varied educational programmes - from a three-year vocational school specializing in arts to an academic level.

The educational concepts were connected with the recognition of an important role of applied arts in social life, also in the aspect of visual culture. A well-developed artistic educational system made Warsaw an important printing centre.
\end{abstract}

